\title{
STUDIES ON THE OCCURRENCE OF SOME HEAVY METALS IN MILK IN LOCAL MARKETS AT PORT. SAID PROVINCE
}

\author{
Mracel F, Galab and Nashwa M. Abdel-Atti \\ Dejst of Food Hygiene, Animal Health Research Institule. Dokkl
}

\begin{abstract}
SUMMARY
The present study aimcd to estimate the tevels of some heavy metals in 50 raw milte samples collected from several supermarkets in different localithes al Port Sald Governorates. The samples were analyzed for the detection of lead, condmint and merciny using Atomic Absorption Spectrophotometer The analytical results reveded that tire mean values of lend .cadmium and mercury in the exarnined raw milk sumples were 3.078 .0 .060 and $0.091 \mathrm{ppm}$ (ng $/ \mathrm{kg}$ ) respectively. The andyzed samples contained lead, cadmiun and mercury above the pernisstble limits. the scrous health hazard for people who could consume such mith were discussed. A regular monitoring of heawy metals contamination of milk is recommended to establish the inse contribulion of milk to the dietary intuke of heavy metals.
\end{abstract}

\section{INTRODUCTION}

Mik contair most of the nutrents neeessary for healthy foud and in sonie groups such as children and elderly , it may constitute the main food or even the only one lLawrance and Frledman, 1995 and Tripathl et al., 1999). Heavy metal residues are hughly toxde but many of them (e.g. Copper and zinc) are essential activators for certain enzynies, vtamins and hormoncs, only at low concentrations. They arc able to accumulatc In the liwing ussues and organs leading to taxicity in man and anlmals,

Contamination of mulk and milk products by chembal pollutants is onc of the major problems confronting publie health. Heavy metals make up one of the most important of pollutant in foot supply (Protasowick1, 1992). From thls group, lcad, cadnium and mercury have recelved incrcasing attention. This attention has ben focuscd due to adverse toxte effects caused by lead (Subramanian, 2988). cadmium (Friberg et al., 1886) and mercury (Manaban, 1989). They arc widcly distributed in alr, agricultural lands, water, cfnucnts from heavy tndustries, drainage, fertilizer , sludge applied in the flelds and stafnless stcel uscel in dairy equipment. (USEPA, 1093: Miner et al., 1997 and Naresh et al., 1999). Lrad and cadmilum are afleus clepwosited in lakrs 
and streams from the air and considered as main source of water pollulion that may be uulized by dalry anlmals or used for washing dairy utenslis [Weslland et al.,1990 and walker, 1990). Animal reecived heavy metals by means of alr , water and feeds (Antontou et al. ,1989). Ingested conlaminated feeding stuffs has theen considered as the main source of metal residues in se. creted milk. Moreover, lead contamlnation from soldered cans is one of post secretory contambnatlon of milk products (Carl, 1991).

In reeent years, much attention has paid to the possible danger of metal poisoning In human. It has been reported that lead, eadnium and mercury are concentrated mastly In the kidney and liver leading to kidney damage and liver eirrhosis. They constitule sever threat to human health due to their cumulative nature resulting in cancer, renal fallure, human hypertension, neuropathy of both central and peripheral nervous system. gastroenteritis, diabetes mellikus antemia and osteomalacia (Muller and Johnsen,1992; Klopow, 1998 and Elfe et al., 1099). Becausc of the high risk associated with the eonsumption of milk with such toxdc pollutarts,

The present study almed to determinc the conccntratlon of lead (Pb). cadmium (CA) and mercury (Hg) In marketed raw milk samples and to set alarm for the publtc about their hazard cfrects.

\section{MATERIAL AND METHODS}

Collection of samples: Filty random samples of masket raw milk were collected from different dalry shops from several localitles in Port Said Govemorates. The collecled samples were transferred to the latoratory to be examined for heavy netals residues. Matkct raw milk samples were subjected to storeh tesl to exclude all samples proved to be heat treated according to schonberg (1956).

Preparation of samples: Rll samples were preparcd according to the inethod described by Hanklnson (1975), $50 \mathrm{ml}$ of milk samples were placed in $250 \mathrm{ml}$ flask. An equal volume of 20 Trichloruacetle acid were added. The samples was shaken for atonit 30 minutes with intervals of Tive minutes and nltercd through a 0.45 u membrane filter. Lsad, cadnilum and mercury in filtered samples were Identified and quantifled by using Pcrkin Elmer 2380 Atomic Absorption Spectrophotometer. The analyucal detection limits for lead, cadmium and mereury were 0.05 . 0.003 and $0.001 \mathrm{ppb}$, respectively .

\section{RESULTS AND DISCUSSION}

From the obtained results, it was clear that, the mean value of lead, cadnium and mercury 
concentrations In examined raw marketed milk samples wcre $1.078 \pm 0.002 \& 0.060 \pm 0.014$ and $0.091 \pm 0.02 \mathrm{ppm}$; respectlvely (table 1), Hyghenje standards of thic conlents of foreign substances in food. state that $0.1 \mathrm{ppm}$ is the maximum lead content in milk Bartic and Piskac, 1981). Hence, all examincd milk samples were above this maxdmum rccommended limits. Lead Is considered one of the most Important poilutants in our envronment and distributed whdely ht classes of natural Foods ( Shehata and Nagah, 1992 ). It ts accumulated poison , Irhibil haemoglobin synthesls (Carl. 1091). and affecting neurological and psychromotor (Ukhun et al.. 1990). Mureover, lead reduce or complete breakdown the function of kidney. liver and brain (Farstner and Wittman, 1983), The mean value of cadmium in examined ratv milk samples were 0.060 prin \pm 0.014 . The results of cadmium were simnlar with those reported by (Murthy and thea, 1968). The levels of cadmlum in the examtned raw mils samples were above the permitssthle $11 \mathrm{mit}[0.005 \mathrm{ppm}$ ] for milk recommended in some conntries as Netherland, Hungary and Germany (Cant, 1891).

Cadmlum is one of the most toxic metals and everyday new data on its toxicity are coming up (Antonlou et al., 1989). It acts on sulfydryle groups of essentlal enzymes and binds to plus. pholiplds and nuclcic aclds, also it has becn shown to interfere with oxldative phosphoryiation and replace zlnc In metal enzymes which changes tis actuity (Carl, 1991). Cadmum Is a posslhle cause or hypertension, kidneyallment and testlcular atrophy (Lovett et al., 1972 ). Moreover, cadmlum may Induce prostate cancer and functonal and morphologlcal changes in many body organs (Lawueryb, 1978). The average of mercury in examined raw milk samples were $0.091 \pm 0.02$ ppin. Similar result were reported by (Gomez and Markakls, 1874), Matvljcuk et al. (1987) and Ruolfattl and Veronese (1990). The concentratlon of incrcury in exantincd raw milk samples excyeeded the gulde llne level $(0.01 \mathrm{ppm})$ for nilk established by Neuhertand. Hungary and Germany (Carl, 1991), Mercury is not essential for man due to Its aflinlly to sulfydryle group in protein , mercury compounds are potent enzyme posson (Rosst and Santaronl, 1976). It causes neurolojelcal effects and einbryotoxictity (Car1, 1991). Moreover, it causes sever kidney damage In both man and anlmal (Manahan, 1989). The obtalned results dcclared that, the concentration of heavy metals in market raw rnllk samples considerably high. this may be due to the different sources of milk samples which depend on the surtounding circuinstances (Baad et al., 2001]. The most probable explanation for the high level of heavy metals in raw markct milk samples may occur during milk tansportation spectally in polluted alr, bad storage, contact with equipment crnployed as mechanlcal milkers, cadmitum plated containers and Tankes lorrics. The transfetred metals from equipmont may excced thosc origlnally present in Uhc datry farm milk (Conl et al., 1999). Based on chronic toxictty studles, the Provisional Tolcrable Weekly Intake ( PTWI) of heavy metals in food for adults ( $60 \mathrm{~kg} \mathrm{~h} . \mathrm{w}$ ) cstablished by bie joint FAO) 
WHO Expert Comnitice on Food Additives, was $0.05 \mathrm{mg} / \mathrm{kg}$ b.w. For lead.0.007 $\mathrm{mg} / \mathrm{kg}$ b.w. for cadnilum and $0.005 \mathrm{mg} / \mathrm{kgg}$ b.w. for mercury. And according to the maximum pormissible limits (M R L) of human dally Intake recorded in Egyptian Organlzation for Standandization and Quallty Control (E 0 \$ $\mathrm{g} \mathrm{C}$, 1993). The level of lead, cadmlum and mercury in the exanunex raw milk samples represents high percent from the acceptable dictary lotake of heavy metals.

Contmuous consumption of inilk with such pollutants may lead to chronic toxsclty lncluding nervous system damage. mental retardation, kfdney dysfunction, nausea, severe collc, drarthea. persistent restiessness and long lasting rashes (Walting Rehm, 1994 and Walker, 1999). So consumption of such milk partlcularly from polluted envtronment may cause human hcalth haxards (Annon, 1006 and Zelterstrom, 1999).

\section{CONCLUSION}

The high lead, cadmium and mereury recorded in examined raw mulk samples constutute a possthle heahth hazardous effecl for man and anlmal. To safcguard human health. a number of factors are taken into account lor controlling heavy metal residues in inllk starting from crop production by application good manufacturing practuce, personal tralning and minimizang use of sludge for land fertilization untll perlodical monitoring of heavy mctals in dilfercnt types of milk. In addition to a veterinary medically orlented prictitiones must be careful per lodical evaluatuon of the animal health and the status of Its products. 
Table (1) : Concentrations of Some Heavy Metals residues ( p.p.m $=\mathrm{mg} / \mathrm{kg}$ ) in raw market milk samples.

\begin{tabular}{|c|c|c|c|c|}
\hline Type & Min. & Max. & Mean & \pm S. E. \\
\hline Lead & 0.983 & 1.160 & 1.078 & 0.002 \\
\hline Cadmium & 0.048 & 0.068 & 0.060 & 0.014 \\
\hline Mercury & 0.081 & 0.099 & 0.091 & 0.02 \\
\hline
\end{tabular}

p.p.m : part per million., Min : Minimum values

Max : Maximum values., S.E. : Slandard Error. 


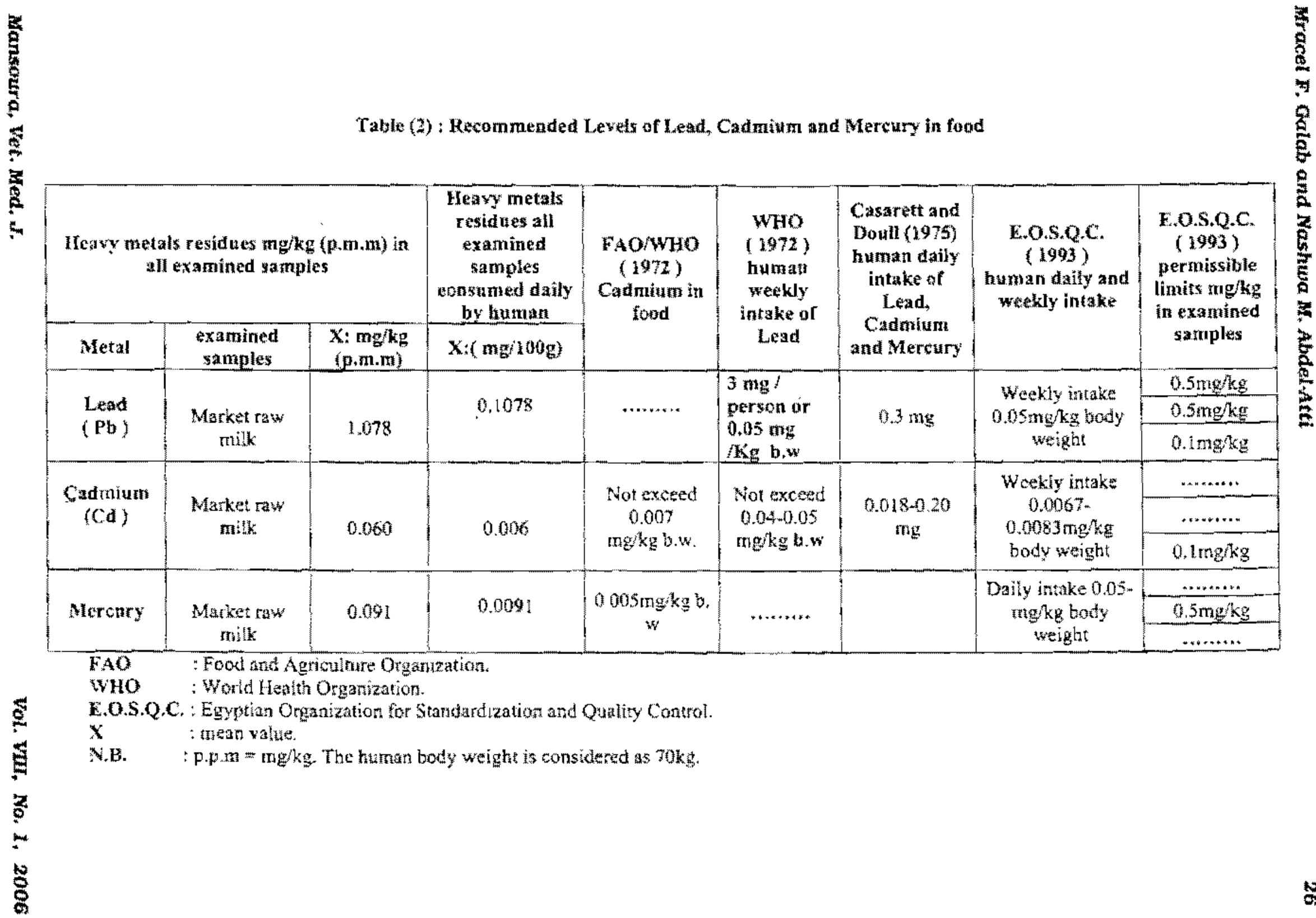




\section{REFERENCES}

Annon, S. (1996) : Clinlcal evaluaton of livestock health hazards dus to envioninenlal pollution with partictuar reference to fluorosis in domestle animal.R\&D report SCAR, New Del. hi.p.58-76.

Antonlou, V.; Tsouknu-Papadopoulou, H.; Epivatiamos, F. and Nathanol, B. (1989) : Cadnlun concentrations in beef consumable ussues in relation to age or animal arid area of their brecding. Bull . Environ. contam. Toxicol .43:915-919.

Bartlc, M. and PAskac. A. (1981) ; Veterinary toxicology. lst ed.Elsevicer scicntific publishing company.Anesterdam,Oxford, Newyork ,p. 108-118.

Carl, M. (1991) : Heavy metals and other trace elements monograph on wisiducs and contaminancs in milk and milk products. Chapler 6.Jnternational daigy Federation.Bolgium ,p.434-566.

Coni. E.; Bocca, B. and Cardl. s. (1999) : Minor and trace elcment content of two typical Itallan daly products. J. Dalry Research 66(2)589-598.

Elfe, R.: Weiss, M; Barros, V.i Slgmund, B.; Gorlup, U.; Komb, D.i Wolf, W.; Klttel, J.; Schramel, P. and Reister, K. (1999) : Chronte polsoning by copper in lap water.Copper Intoxteation with predominatcly gastroinlesunal symplons.Eur J.Mer .Res.4(6) 219-233.

Eosgc, Egyptian organization for standardization and quality contral (1993): Maxilnum residual limit of heavy metals in lood. Ministry of Industry No.2360-2993.p.5 Cairo Egypt.

FAO/ WHO, Joint Expert Committee on food Addltwes .WHO Technical Report Sertes No.505 I 1972): No.555 (1974): No.751 (1987) and Na.776 (1989): Evaluatlon or ecrtalu food Ad ditives and eontaminants. Ceneva,

Forstuer, N. and WIttmann, G. T. W. (1983): Metal pollution in the aquatic Environment.Springer-Verlag, Bertin.

Friberg. L.; Kfellstram, T. and Nordberg. G. F. (1986) : Cadmium in Handbook on the loxdcology or inctals, Vol 2 Finberg L.. Nordierg G.F. And V.B.I cds.] Elscvier. Annesterdaun . pp. $130-184$.

Gomez M. I. and Markakis P. ( 1974) : Mereury content of sonte foods .). Food se1 .39: 673-675.

Hanklnson D. J. (1975) : Potential sourec of copper contamtnatton of farm milk supplies measured by Adomic Absorptoon Spectrophulomeict. J. Dairy sel.58:326.

Mansoura. Vet. Med. J.

Vol. viu, No. 1, 2006 
Blopov, P. V. (1008) : Levels of heavy metals in women residing in the Russian Aretic. Inter. J. Circumpolar Heallh 57 (1) 582.585.

Lawrance, R. and Frledman, L. (1995) ; Contalminants in mllk, In: Hand Book of Milk Compo stuon (Jensen.G. Robert ed.J Academic press 1st Ed.p.857. 990.

Lavuerys, R. R. (1978) : Health effects of cadmlum . In: ferrant E.D. ( ed ) Trace Metals : Exposure and Health Effects. Pergamon Press, Oxford . p. 43.

Lovett, F. J.; Gutenmann, W. H.; Pakkala. L, S.; Younge, W. O, and Lisk, D. J. (1972) : A survey of total cadmium content of 406 fish from 49 New york Iresh water. d. Fish Res. Bd, Canada, $29: 1283-1290$.

Manahan, S. E. (1989) : Toxicological cheinistry, Aguldc to toxic substances in chemlstry . Brooks / cole publishing co . C.A.

Matvljcuk, V. M.; Zulenko V. N.; Belousov, A. L.; Cvirko I. P. and Pazout, V. (1987) : Mercury in milk and milk products, Veterinarstol, $37(11): 491 \cdot 493$. Dairy $\mathrm{Scl}$. Abstract, $51[2], 1989$.

Miner, G.; Guttlerrex, R. and Kling, D. (1997) : Soll factors alfecting plant concentration of cadrntum . copper and zinc on sludge amended soils . J. Environ. Qual . 26 (3)989994.

Muller . W. and Johnsen , D. (1992) : Lebcrwsini tlclverzeher Inden alten und neuen bundes ladern. Emah - rungs. Umschau 39 (1) 47-50.

Clted by Abouzeld, A. M.; Salwa, A. Aly and Ayob, M. M. (2002) : Monteoring studies on the occurrence of some beavy metal reshdues in nilk.Egypt. Vel.med .Ass.62, no , 2: 167174.

Murthy G. B. and Rhea M. (1968) : Cadmlum and silver content of market milk J. Dairy Sct . $51(4): 610 \cdot 613$.

Naresh, R.; Dotvedl, K.; Swarup, D . and Dey, S. (1999) : Lead and cadmium concentrations In inilk and blood of Indian cows with mastits . Vet. Hum . Foxicol , 41 (6) 392-393.

Protasowickt, M. (1992) : Heavy metals content in the selected lood. 3rd world Congress . rood born infectlon and intoxication, 16-19 June. Berlin.

Rlolfatth, M. and Veronese, M. (1090) : Heavy metals in inilk formulas, igcne Modoma .93(6): 1090-1 100.Food Scl.Techn. Abestract, 23(4),1991.

Rosst L. C. and Santaroal M. S. (197g) : Mercury and selenlum distributlon in a defined area and lts population. Archlves of Environnental Health.p. 160-165. 
Saad, A.; EL-Konl, O, and Abdel-Haxtem, E. ( 2001) : Survellence of some heavy metals in raw milk. I st Cong of Food hygrenc \& Human health February .Dept. Food hygicne Fac .Vet. Med. Asslut unlversity ,p .258-270.

Schanberg. (1056) : Milchkunde und milch hygiene 7,Auflage . verlog .M and. H. Schaper , Hannover.Cited by .Abouzerd .A.M.; Salwa. A.Aly and Ayob,M.M.( 200Z).Montloring studies on the occurtence of some heavy metal icsidues in intk. Egypt. Vet. med. Ass.62, no . 2:167-174.

Shehata, A and Nagah, M. S. (1992) : lead conlcnt In mrlk of lactating Arrhals at Assiuk Gov ernorates. Assiut vet. Med J.26(52):135-141.

Subramanlan, X. S. (1988) : Lead .In quantitatuve trace analysis of biologlcal materlals. Mckenzle H.A. and smythe eds.).Elseviet,Ansterdam,pp.589-604.

Trlpathi, M.; R.; Raghunath, R.; Sastry, N. and Krisbanamounrthy. T. (1999) : Dally intake of heavy metals by infants through milk and) milk products. Sel.Tot.tenviron.9( 21229235.

Ukhun, M. E.; Nwazota, J. and Nrwocha, F. O. (1990) : Level of toxic mineral elements in selected loods marketed in NIgerla. Bull.Envirori.Contann.Toxicol, 44:325-330.

USEPA Environmental protection Agency (1993); Clean Water Aet. Section 503.vol.58. No.32USEPA, WashIngton, D.C.P.343-351.

Vesiland, P.; Pierce, J. and Welner. R. (1990) : Water pollution. In: Erivironmental pollution and contwot,3rd tid Londan press, p, 15-36.

Walker, N. 1, (1999) : Copper toxicosls Iu an Austualian ChIld .Eur. J.Med. Res. 28( 6) 249-251.

Walting M. P. and Rehm, S. (1994) : Chronie toxic and careinogende clect of cadnulum cilloride in male Dba/2ncR nice; strain dependent assoctation with tumors of hacrnoblotic system, injection sitc, llver and lung Fundamental and applied toxicology. 231 1]21-31.

2etieratrom, R. (1999) : Child health and environmental pollution in the Aral Sea region in Khazakhastan Acta Paedlatr. suppl. 88( 4)49-54. 


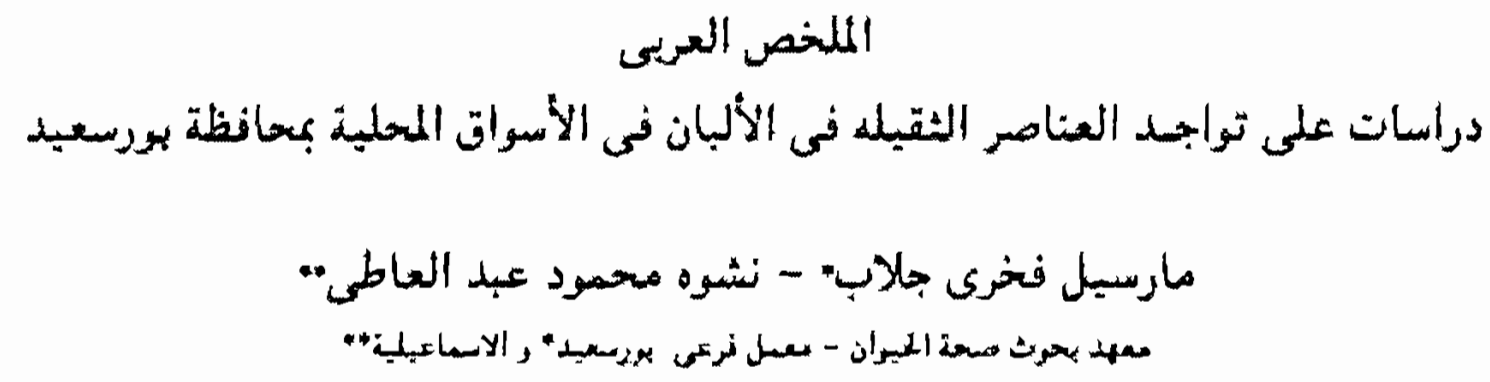

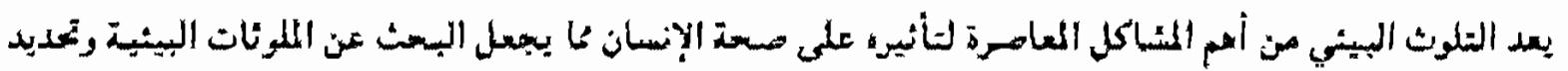

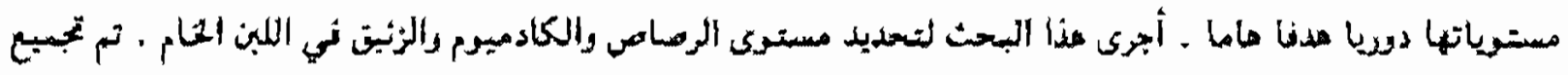

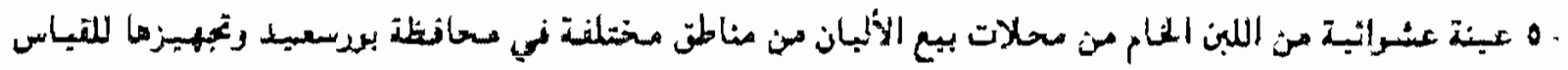

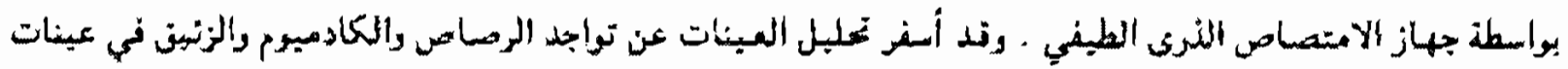

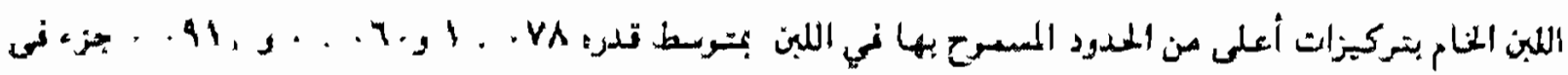

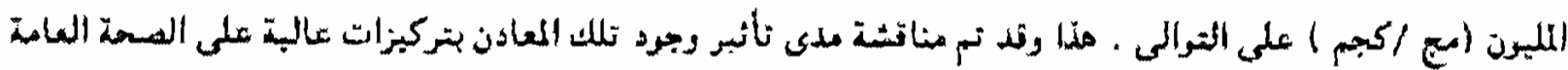
ركذلل الإجراليات والتوصبات الملازمة للمحانطة على صسة الإتهان. 